\title{
Analysis of the Influence of the Beaded Karst on the Pile Additional Settlement
}

\author{
Zhangjun Dai ${ }^{\mathrm{a}}$, Shanxiong Chen $^{\mathrm{b}}$, Xichang Xu, Fei Yu
}

State Key Laboratory of Geomechanics and Geotechnical Engineering, Institute of Rock and Soil Mechanics, Chinese Academy of Sciences, Wuhan, 430071, China

aemail: zjdai@whrsm.ac.cn, bemail:sxchen@whrsm.ac.cn

\section{Keywords: Beaded Karst; Pile Foundation; Additional Settlement}

\begin{abstract}
Pile foundation settlement evaluation in karst area is a very complicated problem, there are many factors that affect the pile deformation, including the size, number and spacing of the karst. In this paper, through numerical simulation, the influence of the number, spacing, size of the karst caves on the additional deformation of the pile foundation are respectively analyzed. The greater the number and the size of karst cave and the smaller the spacing of karst cave, the greater the influence on pile settlement. The cave quantity and size have great influence on the pile settlement proportion.
\end{abstract}

\section{Introduction}

Beaded karst refers to that two or more than two layers of karst distributing in the different depth of the same plane position. The location, shape, scale, development degree, roof thickness and filling characteristics of each karst cave in the beaded karst are different[1-3]. In the construction of pile, the pile will encounter a lot of caves, thus, it becomes one of the most difficult problem to deal with in the construction of pile foundation, which often causes accidents of slurry leakage, sticking, drop hammer, drill burying, etc., and easily leads to quality problems such as concrete erosion during perfusion, entrained mud and pile broken, seriously even causes ground subsidence, settlement of surrounding buildings, groundwater flow stop and other safety and environmental incidents[4-5]. Pile foundation settlement evaluation in karst area is a very complicated problem, which has gotten more and more attention in the engineering field[6-8]. There are many factors that affect the pile deformation, including the size, number and spacing of the karst. In this paper, through numerical simulation, they are respectively explored that the influence of the number, spacing, size of the karst caves on the additional deformation of the pile foundation.

\section{Calculation Scheme}

Beaded karsts mostly contain two caves, and with a maximum of four caves. According to the advanced drilling and electromagnetic wave CT detection results, Figure 1 shows a conceptual model of the beaded karst. The axial symmetry model can be used in ANSYS to carry out numerical simulation of the pile foundation and karst caves, and the calculation model is shown in Figure 2.

The PLANE 82 element and triangle mesh are used in the model, constitutive model is Drucker-Prager, contact elements are set between the pile foundation and formation, the friction material is set on the contact pair, and the friction coefficient is 0.3 , the initial bite force is $9 \mathrm{kPa}$. The material parameters are shown in Table 1.

Table 1 Calculation parameters

\begin{tabular}{|c|c|c|c|c|c|c|}
\hline Material & Lithology & $\begin{array}{c}\text { Density } \\
/ \mathrm{kN} / \mathrm{m}^{3}\end{array}$ & $\begin{array}{c}\text { Elastic modulus } \\
/ \mathrm{MPa}\end{array}$ & Poisson ratio & $\begin{array}{c}c \\
/ \mathrm{kPa}\end{array}$ & $\begin{array}{c}\varphi \\
{ }^{\circ}\end{array}$ \\
\hline Foundation 1 & Pebble & 21 & 50 & 0.27 & 10 & 40 \\
\hline Foundation 2 & Medium weathered rock & 22 & 180 & 0.26 & 80 & 35 \\
\hline Foundation 3 & Slightly weathered rock & 23 & 1000 & 0.23 & 150 & 40 \\
\hline Pile & C40 Reinforced concrete & 26 & 32500 & 0.20 & - & - \\
\hline Karst cave & Soft filler & 13 & 10 & 0.4 & 5 & $8 \sim 10$ \\
\hline
\end{tabular}




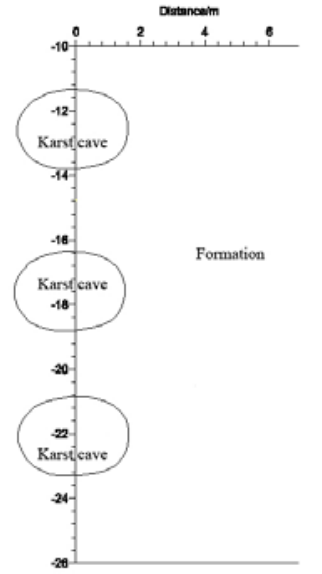

Fig. 1 Conceptual model of the beaded karst

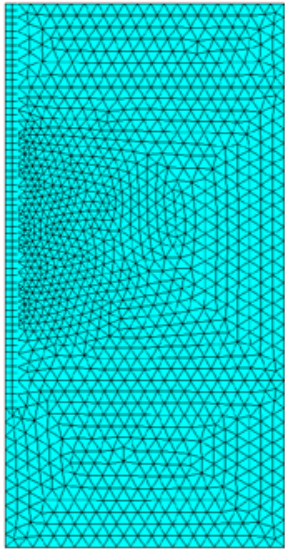

Fig. 2 The calculation model

Take the load of pile foundation and the upper load of pile foundation $624 \mathrm{kPa}$ into consideration in the calculation. It is divided into the following conditions:

Combination conditions 1 : The number of karst cave is respectively $1,2,3$, the diameter is $3.6 \mathrm{~m}$, the spacing is $1.8 \mathrm{~m}$;

Combination condition 2: The number of karst cave is 3 , the height is $3.6 \mathrm{~m}$, the width is respectively $2.4 \mathrm{~m}, 3.6 \mathrm{~m}, 4.8 \mathrm{~m}$, the spacing is $1.8 \mathrm{~m}$;

Combination condition 3: The number of karst cave is 3 , the diameter is $3.6 \mathrm{~m}$, the spacing is respectively $0.6 \mathrm{~m}, 1.2 \mathrm{~m}, 1.8 \mathrm{~m}$.

\section{Analysis of the Influence of Different Karst Cave Features on the Additional Deformation of Pile Foundation Stress}

The additional settlement deformation of pile influenced by the number of the karst cave is shown in Figure 3.

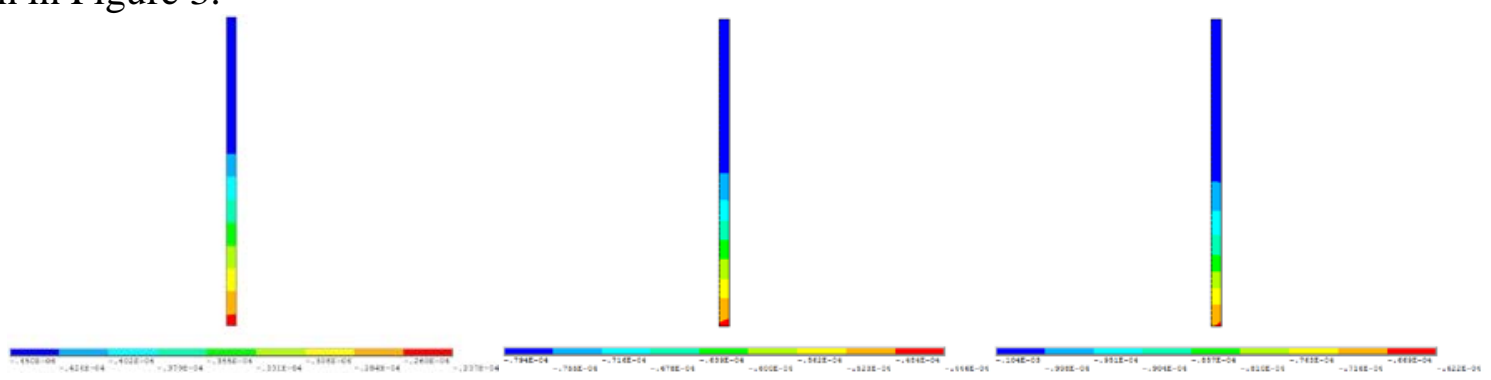
(a) One cave
(b) Two caves
(c) Three caves

Fig. 3 The additional settlement of pile influenced by the cave quantity

Under pile weight and the upper load, the pile top settlement is maximum and it is minimum at the bottom, and the foundation settlement is larger under three hole caves; After cave consolidation settlement, additional settlement of the pile near the cave and the pile top are similar, and the lower part of the pile is farther from the cave, the settlement is smaller, and the additional settlement is the largest under three hole caves.

Table 2 shows the effect of different quantity of karst cave on settlement deformation of pile in each load stage.

Table 2 The effect of different quantity of karst cave on settlement of pile

\begin{tabular}{|c|c|c|c|}
\hline \multirow{2}{*}{ Cave quantity } & \multicolumn{3}{|c|}{ Proportion of pile top settlement /\% } \\
\cline { 2 - 4 } & Pile construction & Upper load & Cave effect \\
\hline 1 & 25.1 & 72.2 & 2.7 \\
\hline 2 & 25.1 & 70.4 & 4.5 \\
\hline 3 & 25.5 & 68.8 & 5.7 \\
\hline
\end{tabular}

The settlement on pile top caused by the pile weight load accounts for about $25 \%$, then it caused by the upper load accounts for about 68\% 72\%, and it caused by karst accounts for about 
$2.7 \% \sim 5.7 \%$. Therefore, the effect of upper load on the pile settlement deformation is the most significant, and the existence of karst has a certain influence on the increase of pile settlement. The greater the number of karst cave, the greater the influence on pile settlement.

The additional settlement deformation of pile influenced by the width of the karst cave is shown in Figure 4.

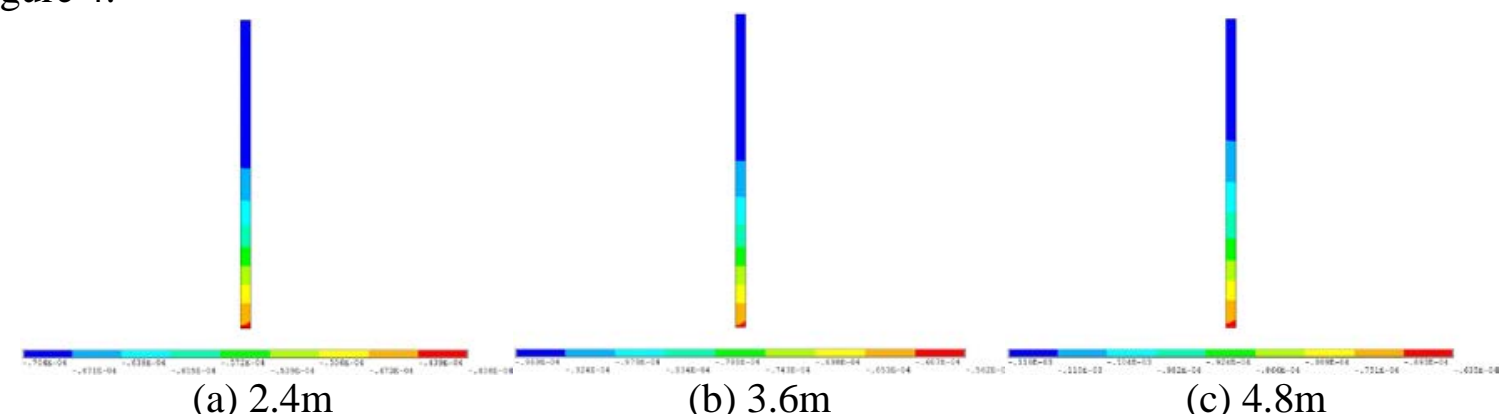
(a) $2.4 \mathrm{~m}$
(b) $3.6 \mathrm{~m}$
(c) $4.8 \mathrm{~m}$

Fig. 4 The additional settlement of pile influenced by the cave width

After cave consolidation settlement, the larger the cave width, the bigger the additional settlement of pile, the maximum additional settlement of the pile is under the width of $4.8 \mathrm{~m}$.

Table 3 shows the effect of different width of karst cave on settlement deformation of pile in each load stage.

Table 3 The effect of different width of karst cave on settlement of pile

\begin{tabular}{|c|c|c|c|}
\hline \multirow{2}{*}{ Cave width $/ \mathrm{m}$} & \multicolumn{3}{|c|}{ Proportion of pile top settlement /\% } \\
\cline { 2 - 4 } & Pile construction & Upper load & Cave effect \\
\hline 2.4 & 25.0 & 70.8 & 4.2 \\
\hline 3.6 & 24.8 & 69.8 & 5.4 \\
\hline 4.8 & 24.9 & 69.0 & 6.1 \\
\hline
\end{tabular}

The settlement on pile top caused by the pile weight load accounts for about $25 \%$, then it caused by the upper load accounts for about 70\%, and it caused by karst accounts for about 4.2\% 6.1\%. The greater the width of karst cave, the greater the influence on pile settlement.

The additional settlement deformation of pile influenced by the spacing of the karst cave is shown in Figure 5.

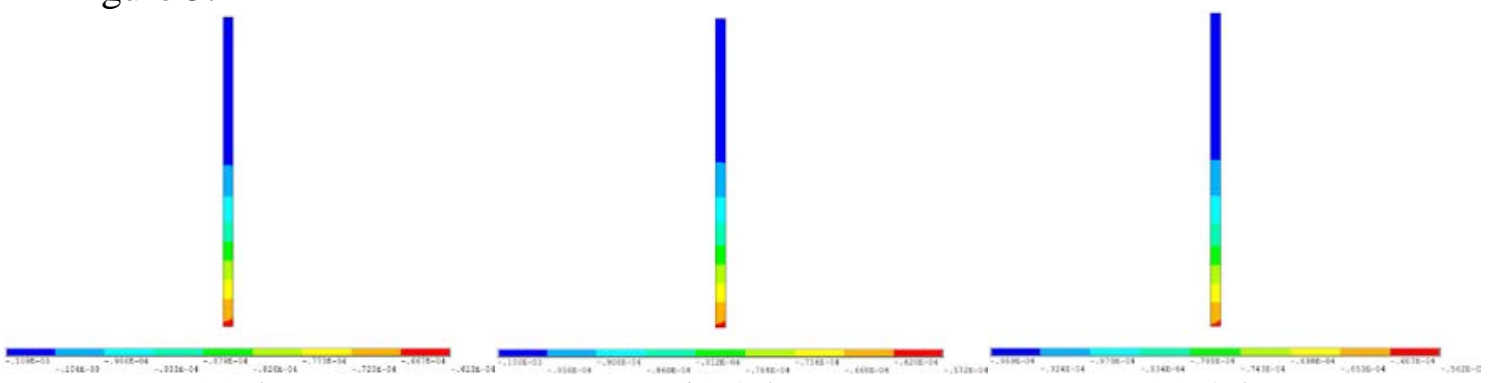
(a) $0.6 \mathrm{~m}$
(b) $1.2 \mathrm{~m}$
(c) $1.8 \mathrm{~m}$

Fig. 5 The additional settlement of pile influenced by the cave spacing

After cave consolidation settlement, the smaller the cave spacing, the bigger the additional settlement of pile, the maximum additional settlement of the pile is under the spacing of $0.6 \mathrm{~m}$.

Table 4 shows the effect of different spacing of karst cave on settlement deformation of pile in each load stage.

Table 4 The effect of different spacing of karst cave on settlement of pile

\begin{tabular}{|c|c|c|c|}
\hline \multirow{2}{*}{ Cave spacing $/ \mathrm{m}$} & \multicolumn{3}{|c|}{ Proportion of pile top settlement $/ \%$} \\
\cline { 2 - 4 } & Pile construction & Upper load & Cave effect \\
\hline 0.6 & 24.88 & 69.16 & 5.96 \\
\hline 1.2 & 25.08 & 69.43 & 5.49 \\
\hline 1.8 & 24.81 & 69.84 & 5.35 \\
\hline
\end{tabular}

The settlement on pile top caused by the pile weight load accounts for about $25 \%$, then it caused by the upper load accounts for about 69\% 70\%, and it caused by karst accounts for about $5.35 \% \sim 5.96 \%$. The smaller the spacing of karst cave, the greater the influence on pile settlement. 


\section{Comprehensive Analysis of the Influence of the Beaded Cave on the Pile Deformation}

Beaded karst makes the pile negative friction, which increases the pile load, but also increases the pile settlement. The influences of cave number, size and spacing on the settlement value of pile are different. Figure 6 shows the variation law of the proportion of the pile foundation settlement controlled by the consolidation settlement of the karst cave under different karst conditions.

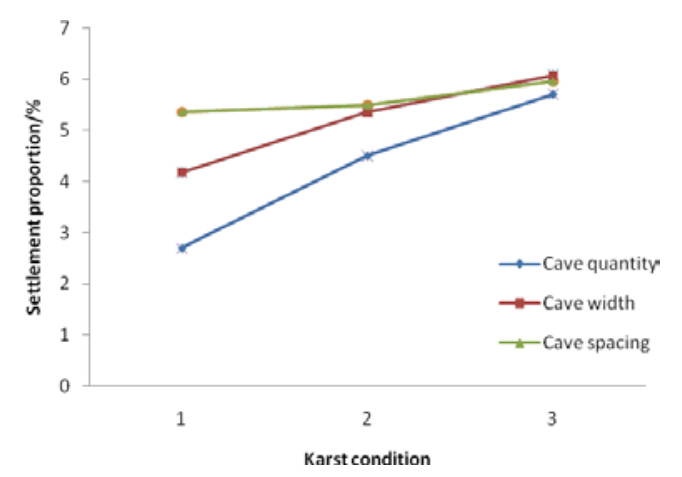

Fig. 6 The proportion of pile settlement under the influence of karst cave

(Karst condition 1,2,3 respectively represents the cave number 1,2,3; the cave width 2.4,3.6,4.8m; the cave spacing $1.8,1.2,0.6 \mathrm{~m}$ )

As can be seen, with the increase of the number of karst cave, the size of the cave and the decrease of the distance between the karst cave, the proportion of the pile foundation settlement caused by the impact of the karst cave is gradually increasing. The cave quantity has great influence on the pile settlement proportion, which increases from $2.7 \%$ of one cave to $5.7 \%$ of three caves, in the case of a $200 \%$ increase in the number of karst cave, the proportion of the settlement increases $111 \%$.

The cave size has also great influence on the pile settlement proportion, under the same conditions of 3 caves, the cave width increases from $2.4 \mathrm{~m}$ to $4.8 \mathrm{~m}$, the proportion increases from $4.2 \%$ to $6.1 \%$, in the case of a $100 \%$ increase in the size of karst cave, the proportion of the settlement increases $45.2 \%$.

The cave spacing has minimum influence on the pile settlement proportion, under the same conditions of 3 caves, the cave spacing reduces from $1.8 \mathrm{~m}$ to $0.6 \mathrm{~m}$, the proportion increases from $5.35 \%$ to $5.96 \%$, karst spacing decreases by $66.7 \%$, the proportion of the settlement only increases $45.2 \%$.

Under the influence of the consolidation settlement of the karst cave, Figure 7 shows the influence of different karst quantity, size and spacing on the proportion of the pile settlement.

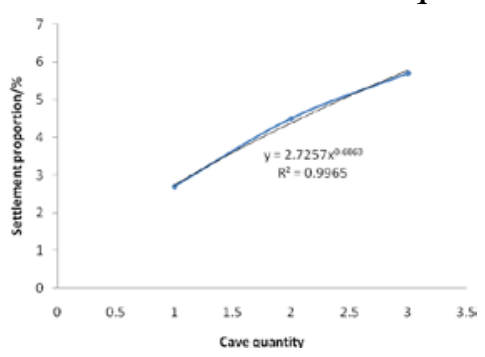

(a) Cave quantity

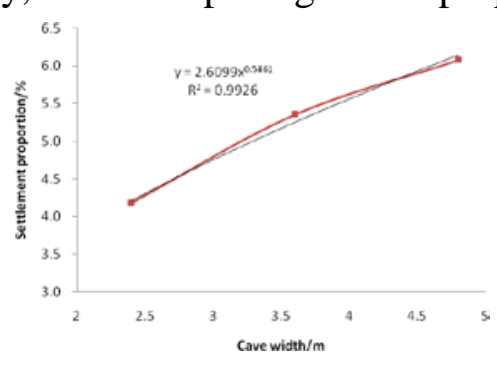

(b) Cave size

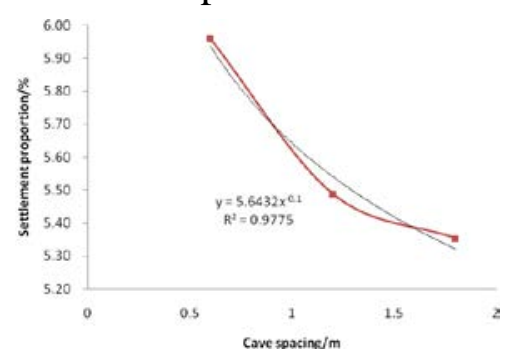

(c) Cave spacing

Fig. 7 Influence of karst cave on additional settlement of pile foundation

It can be seen from Figure 7 (a), with the increase of the number of karst cave, the proportion of the settlement increases, use the power function to fit the empirical formula, the correlation coefficient reaches 0.998 , the fitting formula is

$$
n=2.7257 m^{0.6863}
$$

Where, $m$ is the cave quantity.

It can be seen from Figure 7 (b), with the increase of the width of karst cave, the proportion of the settlement increases, use the power function to fit the empirical formula, the correlation coefficient reaches 0.996 , the fitting formula is 


$$
n=2.6099 b^{0.5461}
$$

Where, $b$ is the cave width (m).

It can be seen from Figure 7 (c), with the decrease of the spacing of karst cave, the proportion of the settlement increases, use the power function to fit the empirical formula, the correlation coefficient reaches 0.989 , the fitting formula is

$$
n=5.6432 d^{-0.1}
$$

Where, $d$ is the cave spacing $(\mathrm{m})$.

\section{Conclusion}

The influence of the number, spacing, size of the karst caves on the additional deformation of the pile foundation are respectively analyzed. The greater the number of karst cave, the greater the influence on pile settlement. The greater the width of karst cave, the greater the influence on pile settlement. The smaller the spacing of karst cave, the greater the influence on pile settlement. The cave quantity and size have great influence on the pile settlement proportion, and the cave spacing has minimum influence on the pile settlement proportion.

\section{References}

[1] Jiang, C., Liu, L., \& Wu, J. P. A new method determining safe thickness of karst cave roof under pile tip [J]. Journal of Central South University,2014 21(3), 1190-1196.

[2] Zheng, W. G., Xie, Y. C., \& Xue, X. B. Selection of pile foundations in karst areas [J]. Yantu Gongcheng Xuebao/chinese Journal of Geotechnical Engineering, 2011 33, 404-407. .

[3] Poulos, H. G., Small, J. C., \& Chow, H. Foundation design for high-rise tower in karstic ground [J]. Geotechnical Special Publication 2013 (229), 720-731.

[4] Zhou, B., Ni, W., Wang, H., \& Liu, Z. Research on bearing capacity of post-grouting pile groups as bridge foundations in karst areas. International Conference on Electric Technology and Civil Engineering. IEEE. 2011 6115-6120.

[5] Sun, Y., Zhang, Z., \& Zhang, H. Analysis on parameter sensitivity of pile foundations stability in karst areas based on the theory of grey relation [J]. Chinese Journal of Underground Space \& Engineering, 2013 9(2), 297-303.

[6] Lodigina, N., \& Sharapov, R. Calculation of pile foundations at the karst areas. International Conference on Mechanical Engineering, Automation and Control Systems. IEEE. 2014

[7] Hua, S., \& Engineering, D. O. Numerical simulation research on the stability of transmission tower pile foundations in a karst area of guangdong province [J]. Carsologica Sinica, 2014 33(1), 44-50.

[8] Niu, J., Oyediran, I. A., Liu, D., Huang, X., Cui, Z., \& Wang, H., et al. Quantitative foundation stability evaluation of urban karst area: case study of tangshan, china [J]. Soils and Foundations, 2015 55(3), 493-503. 